\title{
Household food insecurity in black-slaves descendant communities in Brazil: has the legacy of slavery truly ended?
}

\author{
Muriel B Gubert ${ }^{1, *}$, Anna Maria Segall-Corrêa ${ }^{2}$, Ana Maria Spaniol ${ }^{1}$, Jessica Pedroso ${ }^{1}$, \\ Stefanie Eugênia dos Anjos Campos Coelho ${ }^{1}$ and Rafael Pérez-Escamilla ${ }^{3}$ \\ ${ }^{1}$ Faculdade de Ciências da Saúde, Departamento de Nutrição, Universidade de Brasília, Campus Universitário \\ Darcy Ribeiro, Asa Norte, CEP 70910-900, Brasília, DF, Brazil: ${ }^{2}$ Department of Collective Health, University of \\ Campinas, Campinas, SP, Brazil: ${ }^{3}$ Department of Chronic Disease Epidemiology, Office of Public Health Practice, \\ Yale School of Public Health, New Haven, CT, USA
}

Submitted 5 July 2016: Final revision received 15 November 2016: Accepted 17 November 2016: First published online 20 December 2016

\begin{abstract}
Objective: To identify the factors associated with food insecurity among Quilombolas communities in Brazil.

Design: An analysis of secondary data assessed in the 2011 Quilombolas Census was performed. The Brazilian Food Insecurity Measurement Scale (Escala Brasileira de Insegurança Alimentar, EBIA) was used to assess household food security status. Sociodemographic conditions and access to social programmes and benefits were also evaluated.

Setting: National survey census from recognized Quilombolas Brazilian territories. Subjects: Quilombolas households ( $n$ 8846).

Results: About half (47.8\%) of the Quilombolas lived in severely food-insecure households, with the North and Northeast regions facing the most critical situation. Households located in North Brazil, whose head of the family had less than 4 years of education, with a monthly per capita income below \$US 44, without adequate sanitation and without adequate water supply had the greatest chance of experiencing moderate or severe food insecurity. Households that had access to a water supply programme for dry regions (Programa Cisternas) and an agricultural harvest subsidy programme (Programa Garantia Safra) had less chance of experiencing moderate and severe food insecurity. Households that did not have access to health care (Programa Saúde da Familia) had greater chance of suffering from moderate or severe food insecurity.

Conclusions: Interventions are urgently needed to strengthen and promote public policies aimed to improve living conditions and food security in Quilombolas communities.
\end{abstract}

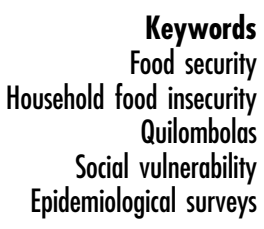

Food and nutrition security is the guaranteed right for all to have access to safe, healthy and nutritious foods in adequate amounts, respecting cultural and social preferences $^{(1,2)}$. The violation of this leads to household food insecurity (HFI), which can range from mild (concerns with food shortage and poor quality of foods due lack of money) to severe (occurrence of hunger) ${ }^{(3)}$. In Brazil, HFI is measured by national surveys using the Brazilian Food Insecurity Measurement Scale (Escala Brasileira de Insegurança Alimentar, EBIA) ${ }^{(3)}$.

Since 2004 Brazil has generated data on household food security from three National Household Representative Surveys ${ }^{(4)}$. Analyses of these data have identified black or brown skin colour, low income and education, and poor health as risk factors for $\mathrm{HFI}^{(3,4)}$.
In 2004 the prevalence of food insecurity among black and brown individuals was $43.4 \%$ compared with $24.6 \%$ among whites. Between 2004 and 2013 this prevalence decreased but still remained higher among black and brown individuals than whites (33.4 v.17.2\%, respectively). In 2013 over half $(50.7 \%)$ of the Brazilian population self-identified as having black or brown skin ${ }^{(5)}$, a characteristic associated with illiteracy and low income. Specifically, illiteracy was $11 \cdot 8 \%$ among black and brown individuals and 5.3\% among whites; furthermore, $14 \cdot 1 \%$ of the black and brown individuals and $5.3 \%$ of the white population were in the lowest income decile. Conversely, among the richest $1 \%$ of the population, only $16.2 \%$ were blacks and $81.6 \%$ were whites ${ }^{(5)}$.

Even though black slavery in Brazil ended in 1888, communities for black individuals still experience major 
socio-economic inequities, especially among those living in slave-descendant communities. These communities are named Quilombos and the people living in them are known as Quilombolas. Quilombos are communities predominantly located in the rural areas of Brazil that were originally founded by runaway black slaves during the slavery period. Quilombos were legally recognized in the Brazilian Constitution in $1988^{(6)}$, although only a few of them were given the right to ownership of their lands. These communities are distributed all over the country and have a relative degree of geographical isolation, a situation associated with difficulties in accessing basic goods and services ${ }^{(7-9)}$. In addition to poverty, Quilombolas experience other social exclusion risk factors including lack of Brazilian State official recognition of their lands, lack of political power and loss of their historically constructed cultural identity ${ }^{(9,10)}$. Quilombolas are legally eligible for social programmes (e.g. the Bolsa Família conditional cash transfer programme), to preferential policies to improve their access to land, to infrastructure development, to actions to promote quality of life, to support for local production and economic autonomy, and to strategies aiming to promote and protect their rights and citizenship (Programa Brasil Quilombola) ${ }^{(11)}$. Unfortunately, to date, these policies have not improved the quality-of-life situation of Quilombolas substantially.

Qualitative and quantitative studies using indirect indicators have shown that Quilombolas communities are at a very high risk of food insecurity ${ }^{(7-9)}$. Quilombolas communities in general have high illiteracy rates, low income, poor access to programmes of several social and agricultural public policies, and difficulties in getting their land ownership legally recognized ${ }^{(9)}$. The situation of extreme poverty faced by most of the Quilombolas families exposes them to food shortages and poor dietary quality, contributing to malnutrition, diseases and other negative health outcomes ${ }^{(2,7,9)}$.

The present study aimed to identify the factors associated with food insecurity among Quilombolas communities in Brazil. In contrast to previous studies, our analysis is based on a direct measure of household food security using the experience-based Brazilian HFI scale (EBIA). Thus, the study's findings can help guide the Government to improve the design and focus of household food security policies for Quilombolas that are still affected by a legacy of major historical inequalities ${ }^{(11)}$.

\section{Methods}

We analysed secondary data from a Census of 169 officially recognized Quilombolas Brazilian territories. This national census was conducted in 2011 under the coordination of the Ministry of Social Development and Fight Against Hunger (Ministério de Desenvolvimento Social e Combate à Fome, MDS) and the identified database is available in the public domain.
The Quilombolas Census assessed the living conditions of 9191 households distributed across fifty-five municipalities located in fourteen Brazilian States, including households with or without children ${ }^{(2)}$. The present study used the household as the unit of analysis and included only those that had complete information regarding the EBIA items (8856 households).

HFI was measured by EBIA. EBIA was originally a fifteen-item scale, but in 2010 one of the questions was excluded as a result of new psychometric analyses ${ }^{(3)}$. Thus, even though the fifteen-item EBIA scale was applied in the Quilombolas survey, we only used the recommended fourteen-item scale in our analyses. EBIA measures different HFI intensities, ranging from questions about worries about running out of food to questions about children not eating for a whole day. An additive household score was computed based on the number of affirmed questions. Based on this score, households were classified as: food secure (score $=0$ ), mildly food insecure (score $=1-5)$, moderately food insecure (score $=6-9)$ or severely food insecure $(\text { score }=10-14)^{(3)}$. EBIA is an adapted and validated version of the US Household Food Security Survey Module ${ }^{(12)}$. The validation process of EBIA in Brazil included Quilombolas communities in the states of São Paulo and Mato Grosso, for both qualitative and quantitative phases, and concluded that EBIA is a valid scale to assess the HFI situation of Quilombolas populations $^{(13)}$.

We conduced descriptive socio-economic and demographic analyses for Quilombolas households located in each one of the five Brazilian regions. These regions have different environmental, climatic and socio-economic characteristics. The following variables were investigated: region; educational level of the head of household; monthly per capita household income, with extreme poverty defined as a monthly per capita income below \$US $44^{(14)}$; enrolment in governmental social assistance programmes, namely the conditional cash transfer programme (Programa Bolsa Família), food assistance programme (Programa Cesta de Alimentos), water cistern supply programme (Programa Cisternas), family agriculture strengthening programme (Programa Nacional de Fortalecimento da Agricultura Familiar, PRONAF) and agriculture subsidy programme (Programa Garantia Safra); household adequate sanitation, defined as having public sewage system or a septic tank; adequate water supply, defined as water available from the public service or appropriately collected spring water; number of individuals in the household; number of children in the household; household visit from a community health worker in the past 2 months; health coverage by the family health programme (Programa Saúde da Família); enrolment in the federal government's single registry (Cadastro Único), an institutional mechanism for accessing the conditional cash transfer and other social protection programmes; household presence of person with physical disability; employment status of the head of 
the household (employed or receiving government retirement; and characteristics of the employment: formal or informal); and earnings from the sale or growth of foods.

The Programa Bolsa Familia is a conditional cash transfer programme for the population living in extreme poverty and provides monthly basic allowances with an additional amount of cash transfer according to the number of eligible individuals in the household. The Programa Cesta de Alimentos distributes food supplies to families in emergency or disaster situations and to specific population groups at high risk of food shortage such as indigenous and Quilombolas communities. The Programa Cisternas aims to promote access to water for human consumption and food production in dry areas by implementing low-cost technologies to store rainwater ${ }^{(15)}$. PRONAF subsidizes credits for small-scale farmers aiming to reduce rural poverty and to promote sustainable rural development. The Programa Garantia Safra has the objective to guarantee minimum earnings to small family farmers susceptible to crop losses due to drought or flood $^{(16)}$. The Programa Saúde da Familia is a health strategy focused on primary health care that includes multidisciplinary teams working in health promotion and disease prevention/control, as well as in the provision of routine care to communities (including visits from community health workers). In Brazil, all individuals, no matter their social status, are entitled to receive free health assistance from the Brazilian Unified Health System or SUS.

The four-level household food (in)security dependent variable was used in the bivariate analyses. For the adjusted analyses, a dichotomous dependent variable was created by combining secure and mildly food insecure into one category (reference group) and moderately and severely food insecure into the other category. We combined HFI categories as done in previous studies ${ }^{(17,18)}$, allowing us to contrast two distinct HFI groups. The food secure/mild food insecure group is expected to not experience or to experience small reductions in dietary quality, without reductions in amount of food or following unusual food access coping patterns. By contrast, the moderately/severely food insecure is expected to experience major deterioration in dietary quality and quantity to the point of having household members experiencing hunger once the coping strategies used to sustain energy intake become ineffective ${ }^{(12)}$.

Bivariate analyses were performed using the $\chi^{2}$ test to investigate the association between demographic and socio-economic variables and the dependent variable (HFI). Subsequently, a multivariate analysis with a binary logistic regression model was conducted to generate unadjusted odds ratios for HFI.

Adjusted analyses were performed using a logistic regression model to calculate adjusted odds ratios for HFI $\left(\mathrm{OR}_{\mathrm{adj}}\right)$. We included the independent variables that in the bivariate analyses were associated with HFI with $P<0 \cdot 10$.
Initially we included the block of distal independent variables (i.e. sanitation, water supply, earnings from the sale or growth of foods, enrolment in social programmes (Cadastro Único, Programa Bolsa Família, Programa Cesta de Alimentos, Programa Cisternas, Programa Garantia Safra, PRONAF and Programa Saúde da Familia) and visit of the community health worker). Then we tested the block of proximal independent variables, such as household presence of person with physical disability, employment status of the head of the household, number of individuals in the household, number of children in the household, income and educational level. The final model included the variables that remained associated with HFI with $P<0 \cdot 05$. These were: per capita household income, educational level of the head of the household, region, Programa Bolsa Familia, Programa Cisternas, Programa Garantia Safra, adequate water supply, adequate sanitation, number of individuals in the household, provision of care by the Programa Saúde da Familia and employment status of the head of the household. The final $P$ value for model fit was $<0 \cdot 001$.

All analyses were performed using the statistical software package IBM SPSS Statistics Version 20.0. The data came from a Census including all Quilombolas households, thus sample weights were not needed for the statistical analysis.

\section{Results}

The present study found a low prevalence of food security (14.4\%) and a high prevalence of severe HFI (47.8\%) among the Quilombolas population. The majority of Quilombolas lived in the North and Northeast regions (84.3\%; data not shown). In the North of Brazil, severe HFI affects $62 \cdot 3 \%$ of the Quilombolas (Table 1 ).

The educational level of the Quilombolas was low, with $31.2 \%$ of heads of household having less than 4 years of education and only $1.8 \%$ having more than 9 years. The majority of the Quilombolas lived with a monthly per capita household income below \$US 44 (45.0\%). The prevalence of extreme poverty among the Quilombolas living in the North region was $48.4 \%$ v. $15.7 \%$ among Quilombolas from the South/Southeast.

With regard to social programmes, $61.2 \%$ of Quilombolas households received a cash transfer from Programa Bolsa Família. Only $14.8 \%$ of Quilombolas households had adequate sanitation and $44.1 \%$ had adequate water supply. Our data showed that 38.6\% of the heads of household were unemployed, the majority of whom lived in the Midwest region (58.7\%), and only $10.0 \%$ of them had a formal employment contract. Only $21.8 \%$ of Quilombolas households complemented their income with the sale or growth of foods, a percentage that was highest in the North region (26.5\%). 
Table 1 Descriptive analysis of the population: demographic aspects of the Quilombolas population in Brazil and its regions. Brazil, Census of Titled Quilombola Communities (Censo de Comunidades Quilombolas Tituladas), 2011

\begin{tabular}{|c|c|c|c|c|c|c|c|c|c|c|}
\hline \multirow[b]{2}{*}{ Study variable } & \multicolumn{2}{|c|}{ Brazil } & \multicolumn{2}{|c|}{ South/Southeast } & \multicolumn{2}{|c|}{ Midwest } & \multicolumn{2}{|c|}{ Northeast } & \multicolumn{2}{|c|}{ North } \\
\hline & $n$ & $\%$ & $n$ & $\%$ & $n$ & $\%$ & $n$ & $\%$ & $n$ & $\%$ \\
\hline \multicolumn{11}{|l|}{ Household food security status } \\
\hline Food security & 1277 & 14.4 & 173 & $49 \cdot 0$ & 190 & $18 \cdot 7$ & 453 & $16 \cdot 7$ & 461 & $9 \cdot 7$ \\
\hline Mildly food insecure & 1557 & $17 \cdot 6$ & 116 & 32.9 & 353 & 34.7 & 644 & 23.7 & 44 & $9 \cdot 3$ \\
\hline Moderately food insecure & 1785 & $20 \cdot 2$ & 35 & 9.9 & 276 & $27 \cdot 2$ & 587 & 21.6 & 887 & $18 \cdot 6$ \\
\hline Severely food insecure & 4227 & $47 \cdot 8$ & 29 & $8 \cdot 2$ & 2197 & $19 \cdot 4$ & 1036 & $38 \cdot 1$ & 2965 & $62 \cdot 3$ \\
\hline \multicolumn{11}{|c|}{ Educational level of the head of the household } \\
\hline Up to 4 years & 2819 & 31.2 & 59 & $16 \cdot 3$ & 513 & 48.4 & 1121 & $40 \cdot 7$ & 1126 & $23 \cdot 2$ \\
\hline From 5 to 8 years & 6047 & $66 \cdot 9$ & 294 & 81.4 & 532 & $50 \cdot 2$ & 1576 & $57 \cdot 2$ & 3645 & $75 \cdot 0$ \\
\hline 9 years or more & 170 & 1.8 & 8 & $2 \cdot 2$ & 15 & 1.4 & 58 & $2 \cdot 1$ & 89 & 1.8 \\
\hline \multicolumn{11}{|l|}{ Monthly per capita household income } \\
\hline Below \$US 44.00 & 4135 & $45 \cdot 0$ & 58 & $15 \cdot 7$ & 433 & $40 \cdot 2$ & 1251 & 44.6 & 2393 & 48.4 \\
\hline From \$US 44.00 to $\$$ US 160.00 & 3121 & 33.9 & 156 & $42 \cdot 3$ & 321 & 29.8 & 965 & 34.4 & 1679 & 34.0 \\
\hline Above \$US 160.00 & 1937 & $21 \cdot 1$ & 155 & $42 \cdot 0$ & 322 & 29.9 & 589 & 21.0 & 871 & $17 \cdot 6$ \\
\hline \multicolumn{11}{|l|}{ Social programmes and benefits } \\
\hline \multicolumn{11}{|l|}{ Programa Bolsa Família } \\
\hline Yes & 5608 & $61 \cdot 2$ & 160 & 43.8 & 598 & 55.7 & 1930 & $69 \cdot 3$ & 2920 & $59 \cdot 3$ \\
\hline No & 3554 & 38.8 & 205 & $56 \cdot 2$ & 476 & $44 \cdot 3$ & 866 & 31.0 & 2007 & $40 \cdot 7$ \\
\hline \multicolumn{11}{|l|}{ Programa Cesta de Alimentos } \\
\hline Yes & 2889 & 31.6 & 206 & $56 \cdot 3$ & 784 & 73.4 & 1290 & $46 \cdot 3$ & 609 & $12 \cdot 4$ \\
\hline No & 6254 & $68 \cdot 4$ & 160 & 43.7 & 284 & $26 \cdot 6$ & 1499 & 53.7 & 4311 & $87 \cdot 6$ \\
\hline \multicolumn{11}{|l|}{ Programa Cisternas } \\
\hline Yes & 432 & 4.7 & 7 & 1.9 & 6 & 0.6 & 405 & 14.5 & 14 & 0.3 \\
\hline No & 8734 & $95 \cdot 3$ & 362 & 98.1 & 1065 & 99.4 & 2392 & 85.5 & 4915 & $99 \cdot 7$ \\
\hline \multicolumn{11}{|l|}{ PRONAF } \\
\hline Yes & 511 & 5.9 & 35 & 11.3 & 55 & 5.3 & 194 & 7.6 & 227 & 4.8 \\
\hline No & 8094 & $94 \cdot 1$ & 274 & 88.7 & 977 & 94.7 & 2375 & 92.4 & 4468 & $95 \cdot 2$ \\
\hline \multicolumn{11}{|l|}{ Programa Garantia Safra } \\
\hline Yes & 353 & $4 \cdot 1$ & 4 & 1.3 & 3 & 0.3 & 332 & $12 \cdot 9$ & 14 & 0.3 \\
\hline No & 8270 & 95.9 & 307 & 98.7 & 1027 & 99.7 & 2243 & $87 \cdot 1$ & 4693 & $99 \cdot 7$ \\
\hline \multicolumn{11}{|l|}{ Adequate sanitation } \\
\hline Yes & 1350 & $14 \cdot 8$ & 212 & $58 \cdot 6$ & 237 & $22 \cdot 1$ & 578 & $20 \cdot 9$ & 323 & 6.6 \\
\hline No & 7775 & $85 \cdot 2$ & 150 & 41.4 & 835 & 77.9 & 2193 & $79 \cdot 1$ & 4597 & 93.4 \\
\hline \multicolumn{11}{|l|}{ Adequate water supply } \\
\hline Yes & 4037 & $44 \cdot 1$ & 321 & $87 \cdot 7$ & 426 & 39.7 & 1223 & $43 \cdot 8$ & 2067 & $42 \cdot 1$ \\
\hline No & 5108 & 55.9 & 45 & $12 \cdot 3$ & 647 & $60 \cdot 3$ & 1572 & $56 \cdot 2$ & 2844 & 57.9 \\
\hline \multicolumn{11}{|c|}{ Number of individuals in the household } \\
\hline Up to 4 individuals & 5247 & $57 \cdot 1$ & 256 & 69.4 & 751 & $69 \cdot 8$ & 1740 & $62 \cdot 0$ & 2500 & $50 \cdot 6$ \\
\hline From 5 to 7 individuals & 3063 & 33.3 & 95 & $25 \cdot 7$ & 264 & 24.5 & 859 & $30 \cdot 6$ & 1845 & $37 \cdot 3$ \\
\hline More than 8 individuals & 883 & 9.6 & 18 & 4.9 & 61 & $5 \cdot 7$ & 206 & $7 \cdot 3$ & 598 & $12 \cdot 1$ \\
\hline \multicolumn{11}{|l|}{ Number of children in the household } \\
\hline 1 child & 7917 & $86 \cdot 1$ & 341 & 92.4 & 961 & $89 \cdot 3$ & 2466 & 87.9 & 4149 & 83.9 \\
\hline More than 2 children & 1276 & 13.9 & 28 & 7.6 & 115 & $10 \cdot 7$ & 339 & $12 \cdot 1$ & 794 & $16 \cdot 1$ \\
\hline Visit of the community health work & & & & & & & & & & \\
\hline Yes & 6823 & 74.6 & 263 & 71.9 & 922 & $86 \cdot 2$ & 2146 & $76 \cdot 9$ & 3492 & 71.0 \\
\hline No & 2317 & $25 \cdot 4$ & 103 & 28.1 & 147 & $13 \cdot 8$ & 644 & $23 \cdot 1$ & 1423 & $29 \cdot 0$ \\
\hline Provision of care by Programa Sal & & & & & & & & & & \\
\hline Yes & 3244 & $35 \cdot 6$ & 300 & $83 \cdot 3$ & 319 & 29.8 & 1522 & 54.8 & 1103 & 22.5 \\
\hline No & 5865 & 64.4 & 60 & $16 \cdot 7$ & 752 & $70 \cdot 2$ & 1253 & $45 \cdot 2$ & 3800 & 77.5 \\
\hline
\end{tabular}


The analysis of the association between the variables investigated and HFI status (Table 2) showed that higher socio-economic conditions were inversely associated with HFI. Crude regression analysis revealed that households located in the North region of Brazil had 19.22 (95\% CI $14.52,25.44)$ times higher odds of experiencing moderate or severe food insecurity than those located in the South or Southeast region of Brazil. Similarly, households whose head had less than 4 years of education $(\mathrm{OR}=2.54 ; 95 \%$ CI 1.84, 3.50) and those with monthly per capita household income below \$US 44 (OR=4.19; $95 \%$ CI $3.72,4.72)$ were more likely to present a higher prevalence of severe HFI. Households that were not receiving cash transfer from Programa Bolsa Família (OR=0.51; 95\% CI 0.46, 0.56), were not registered in Cadastro Único $(\mathrm{OR}=0.55$; $95 \%$ CI $0.50,0.61)$ and were not receiving earnings from selling or growing foods (OR $=0.59 ; 95 \% \mathrm{CI} 0.52,0.66$ ) had a lower prevalence of moderate or severe HFI.

Adjusted logistic regressions analyses showed that households located in the North $v$. the South/Southeast region $\left(\mathrm{OR}_{\mathrm{adj}}=11 \cdot 26 ; 95 \% \mathrm{CI} 7 \cdot 83,16 \cdot 19\right)$, who had heads of household with low levels of education $\left(\mathrm{OR}_{\mathrm{adj}}=1.92\right.$; $95 \%$ CI $1.29,2 \cdot 85)$ and in extreme poverty $\left(\mathrm{OR}_{\mathrm{adj}}=2 \cdot 78\right.$; $95 \%$ CI $2 \cdot 36,3 \cdot 29)$ had higher odds of moderate to severe food insecurity (Table 3 ).

Households that did not have access to Programa Cisterna and Garantia Safra had 1.35 (95\% CI 1.06, 1.72) and $1.43(95 \%$ CI $1.41,1.85)$ times higher chance of experiencing moderate/severe HFI, respectively. Households not receiving benefits from Programa Bolsa Família were less likely to experience the most severe forms of food insecurity $\left(\mathrm{OR}_{\mathrm{adj}}=0.66\right.$; $\left.95 \% \mathrm{CI} 0.58,0.75\right)$. Moreover, households that did not have access to the Programa Saúde da Família had 1.40 (95\% CI 1.25, 1.58) times higher adjusted odds for moderate/severe HFI (Table 3).

Households without adequate sanitation $\left(\mathrm{OR}_{\mathrm{adj}}=1 \cdot 88\right.$; $95 \%$ CI $1.61,2.19)$ and without adequate water supply $\left(\mathrm{OR}_{\mathrm{adj}}=1.23 ; 95 \%\right.$ CI $\left.1.10,1.39\right)$ were more likely to present moderate/severe HFI. Finally, households whose head was unemployed had 1.11 (95\% CI 0.98 , 1.26) times higher adjusted odds of experiencing moderate/severe HFI.

\section{Discussion}

The prevalence of HFI observed in the Quilombolas Census (85.6\%) was higher than that found in smaller studies that also used the EBIA to evaluate HFI. Investigating Quilombolas communities in the state of Tocantins (North Brazil), Monego et al. ${ }^{(8)}$ found that $85.1 \%$ experienced HFI, with $32.9 \%$ experiencing moderate HFI and $14.9 \%$ severe HFI. In that study HFI was associated with community-level variables such as water supply, sewage and garbage collection infrastructure. Cordeiro et al. ${ }^{(19)}$ found in Quilombolas communities in the state of Goiás 
Table 2 Determinants of food and nutrition insecurity and demographic aspects in the Brazilian Quilombolas population. Brazil, Census of Titled Quilombola Communities (Censo de Comunidades Quilombolas Tituladas), 2011

\begin{tabular}{|c|c|c|c|c|c|c|c|c|c|c|}
\hline \multirow[b]{2}{*}{ Study variable* } & \multicolumn{2}{|c|}{ Food security } & \multicolumn{2}{|c|}{ Mild food insecurity } & \multicolumn{2}{|c|}{ Moderate food insecurity } & \multicolumn{2}{|c|}{ Severe food insecurity } & \multirow[b]{2}{*}{ Unadjusted OR† } & \multirow[b]{2}{*}{$95 \% \mathrm{Cl}$} \\
\hline & $n$ & $\%$ & $n$ & $\%$ & $n$ & $\%$ & $n$ & $\%$ & & \\
\hline \multicolumn{11}{|l|}{ Region } \\
\hline South/Southeast & 173 & $49 \cdot 0$ & 116 & 32.9 & 35 & 9.9 & 29 & $8 \cdot 2$ & 1.00 & - \\
\hline Midwest & 190 & $18 \cdot 7$ & 353 & 34.7 & 276 & $27 \cdot 2$ & 197 & $19 \cdot 4$ & 3.93 & $2.92,5.30$ \\
\hline Northeast & 453 & $16 \cdot 7$ & 644 & $23 \cdot 7$ & 587 & 21.6 & 1036 & $38 \cdot 1$ & 6.68 & $5.04,8.85$ \\
\hline North & 461 & 9.7 & 444 & 9.3 & 887 & 18.6 & 2965 & $62 \cdot 3$ & $19 \cdot 22$ & $14.52,25.44$ \\
\hline \multicolumn{11}{|c|}{ Educational level of the head of the household } \\
\hline Up to 4 years & 393 & 14.5 & 443 & $16 \cdot 3$ & 520 & $19 \cdot 2$ & 1355 & $50 \cdot 0$ & 2.54 & $1.84,3.50$ \\
\hline From 5 to 8 years & 808 & 13.9 & 1044 & 17.9 & 1202 & $20 \cdot 6$ & 2771 & 47.6 & 2.43 & $1.77,3.33$ \\
\hline 9 years or more & 40 & $25 \cdot 0$ & 45 & $28 \cdot 1$ & 40 & $25 \cdot 0$ & 35 & 21.9 & 1.00 & - \\
\hline \multicolumn{11}{|l|}{ Monthly per capita household income } \\
\hline Below $\$$ US 44.00 & 280 & $7 \cdot 0$ & 559 & $14 \cdot 0$ & 759 & $19 \cdot 1$ & 2385 & 59.9 & 4.19 & $3.72,4.72$ \\
\hline From $\$$ US 44.00 to $\$$ US 160.00 & 403 & 13.5 & 605 & $20 \cdot 2$ & 680 & $22 \cdot 7$ & 1305 & $43 \cdot 6$ & $2 \cdot 20$ & $1.96,2.48$ \\
\hline Above \$US 160.00 & 594 & 31.8 & 393 & 21.0 & 346 & 18.5 & 537 & $28 \cdot 7$ & 1.00 & - \\
\hline \multicolumn{11}{|l|}{ Social programmes and benefits } \\
\hline \multicolumn{11}{|l|}{ Programa Bolsa Família } \\
\hline Yes & 480 & 8.9 & 939 & $17 \cdot 4$ & 1180 & 21.8 & 2811 & $52 \cdot 0$ & 1.00 & - \\
\hline No & 790 & $23 \cdot 2$ & 613 & $18 \cdot 0$ & 598 & 17.5 & 1408 & 41.3 & 0.51 & $0.46,0.56$ \\
\hline \multicolumn{11}{|l|}{ Programa Cesta de Alimentos } \\
\hline Yes & 521 & $18 \cdot 7$ & 710 & 25.5 & 530 & $19 \cdot 0$ & 1027 & $36 \cdot 8$ & 1.00 & - \\
\hline \multirow{2}{*}{\multicolumn{11}{|c|}{ Programa Cisternas }} \\
\hline & & & & & & & & & & \\
\hline Yes & 69 & $16 \cdot 5$ & 128 & 30.5 & 99 & $23 \cdot 6$ & 123 & $29 \cdot 4$ & 1.00 & - \\
\hline \multirow{2}{*}{\multicolumn{11}{|c|}{ PRONAF }} \\
\hline & & & & & & & & & & \\
\hline Yes & 71 & 14.5 & 112 & $22 \cdot 9$ & 112 & $22 \cdot 9$ & 195 & $39 \cdot 8$ & 1.00 & - \\
\hline \multirow{2}{*}{\multicolumn{11}{|c|}{ Programa Garantia Safra }} \\
\hline & & & & & & & & & & \\
\hline Yes & 45 & $13 \cdot 1$ & 107 & 31.2 & 73 & $21 \cdot 3$ & 118 & 34.4 & 1.00 & - \\
\hline \multirow{2}{*}{\multicolumn{11}{|c|}{ Adequate sanitation }} \\
\hline & & & & & & & & & & \\
\hline Yes & 353 & $27 \cdot 1$ & 384 & 29.5 & 268 & $20 \cdot 6$ & 198 & $22 \cdot 9$ & 1.00 & - \\
\hline No & 913 & $12 \cdot 2$ & 1164 & $15 \cdot 6$ & 1505 & $20 \cdot 1$ & 3898 & $52 \cdot 1$ & 3.39 & $3.00,3.82$ \\
\hline Adequate water supply & & & & & & & & & & \\
\hline Yes & 731 & $18 \cdot 9$ & 758 & $19 \cdot 6$ & 788 & $20 \cdot 4$ & 1586 & $41 \cdot 1$ & 1.00 & - \\
\hline No & 534 & $10 \cdot 8$ & 794 & $16 \cdot 1$ & 993 & $20 \cdot 1$ & 2617 & 53.0 & 1.70 & $1.56,1.87$ \\
\hline Number of individuals in the house & & & & & & & & & & \\
\hline Up to 4 individuals & 976 & $19 \cdot 4$ & 994 & $19 \cdot 7$ & 1019 & $20 \cdot 2$ & 1044 & $40 \cdot 6$ & 1.00 & - \\
\hline From 5 to 7 individuals & 261 & 8.8 & 470 & $15 \cdot 9$ & 633 & 21.4 & 1589 & 53.8 & 1.95 & $1 \cdot 77,2 \cdot 16$ \\
\hline More than 8 individuals & 40 & 4.7 & 93 & $10 \cdot 8$ & 133 & 15.5 & 594 & $69 \cdot 1$ & 3.52 & $2 \cdot 90,4.26$ \\
\hline Number of children in the househo & & & & & & & & & & \\
\hline 1 child & 1176 & $15 \cdot 5$ & 1385 & $18 \cdot 2$ & 1534 & $20 \cdot 2$ & 3514 & $46 \cdot 2$ & 1.00 & - \\
\hline More than 2 children & 101 & $8 \cdot 2$ & 172 & 13.9 & 251 & $20 \cdot 3$ & 713 & $57 \cdot \overline{6}$ & 1.79 & $1.55,2.07$ \\
\hline Visit of the community health work & & & & & & & & & & \\
\hline Yes & 985 & 14.9 & 1225 & 18.6 & 1384 & $21 \cdot 0$ & 3006 & 45.5 & 1.00 & - \\
\hline No & 282 & $12 \cdot 8$ & 327 & 14.9 & 392 & $17 \cdot 8$ & 1197 & 54.5 & 1.31 & $1 \cdot 18,1.46$ \\
\hline Provision of care by Programa Sa & & & & & & & & & & \\
\hline Yes & 671 & 21.5 & 680 & $21 \cdot 8$ & 641 & 20.5 & 1132 & $36 \cdot 2$ & 1.00 & - \\
\hline No & 593 & 10.5 & 862 & $15 \cdot 3$ & 1127 & $20 \cdot 0$ & 3062 & $54 \cdot 3$ & 2.19 & $2 \cdot 00,2 \cdot 41$ \\
\hline Enrolment in Cadastro Único & & & & & & & & & & \\
\hline Yes & 621 & $10 \cdot 3$ & 1066 & $17 \cdot 6$ & 1272 & $21 \cdot 0$ & 3093 & $51 \cdot 1$ & 1.00 & - \\
\hline No & 652 & $23 \cdot 6$ & 485 & $17 \cdot 6$ & 506 & $18 \cdot 3$ & 1115 & 40.4 & 0.55 & $0.50,0.61$ \\
\hline
\end{tabular}




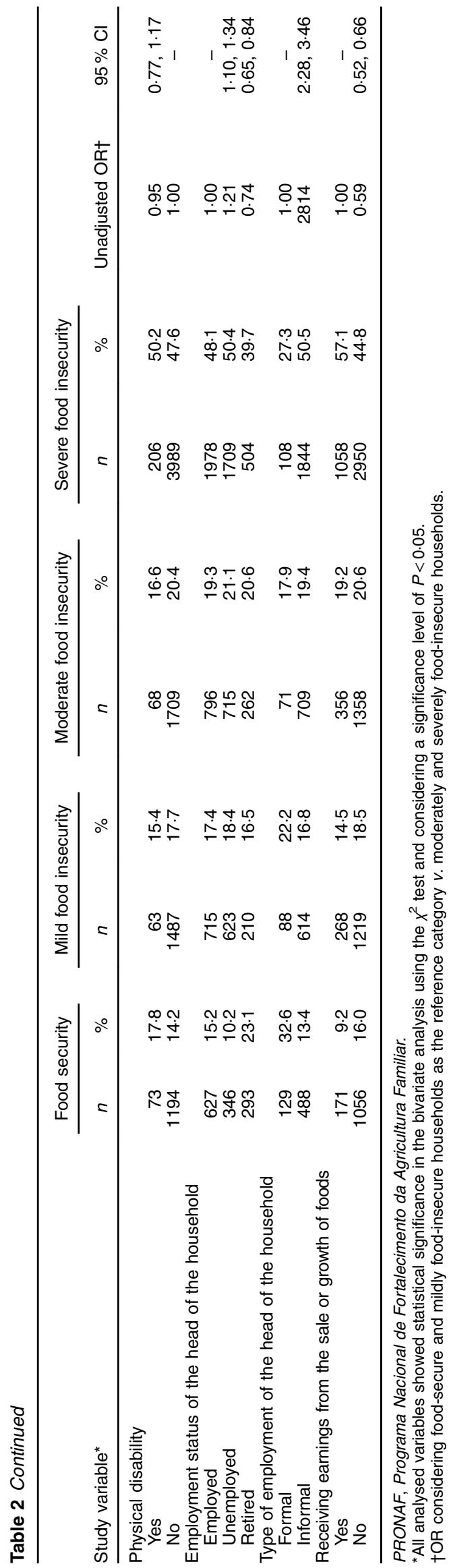

Table 3 Determinants of food and nutrition security and demographic aspects in the Brazilian Quilombola population. Brazil, Census of Titled Quilombola Communities (Censo de Comunidades Quilombolas Tituladas), 2011

\begin{tabular}{|c|c|c|}
\hline Study variable* & Adjusted OR† & $95 \% \mathrm{Cl}$ \\
\hline \multicolumn{3}{|l|}{ Region } \\
\hline South/Southeast & 1.00 & - \\
\hline Midwest & $2 \cdot 33$ & $1.59,3.42$ \\
\hline Northeast & 4.48 & $3 \cdot 12,6 \cdot 44$ \\
\hline North & $11 \cdot 26$ & $7 \cdot 83,16 \cdot 1 \mathrm{c}$ \\
\hline \multicolumn{3}{|l|}{$\begin{array}{l}\text { Educational level of the head of the } \\
\text { household }\end{array}$} \\
\hline Up to 4 years & 1.92 & $1.29,2.85$ \\
\hline From 5 to 8 years & 1.34 & $0.91,1.97$ \\
\hline 9 years or more & 1.00 & - \\
\hline \multicolumn{3}{|l|}{ Monthly per capita household income } \\
\hline Below \$US 44.00 & $2 \cdot 78$ & $2 \cdot 36,3.29$ \\
\hline From \$US 44.00 to $\$$ US 160.00 & 1.61 & $1.37,1.89$ \\
\hline Above $\$ \cup \$ 160 \cdot 00$ & 1.00 & - \\
\hline \multicolumn{3}{|l|}{ Social programmes and benefits } \\
\hline \multicolumn{3}{|l|}{ Programa Bolsa Família } \\
\hline Yes & 1.00 & - \\
\hline No & 0.66 & $0.58,0.75$ \\
\hline \multicolumn{3}{|l|}{ Programa Cisternas } \\
\hline Yes & 1.00 & - \\
\hline No & 1.35 & $1.06,1.72$ \\
\hline \multicolumn{3}{|l|}{ Programa Garantia Safra } \\
\hline Yes & 1.00 & - \\
\hline \multirow{2}{*}{\multicolumn{3}{|c|}{ Adequate sanitation }} \\
\hline & & \\
\hline Yes & 1.00 & - \\
\hline No & 1.88 & $1.61,2.19$ \\
\hline \multicolumn{3}{|l|}{ Adequate water supply } \\
\hline Yes & 1.00 & - \\
\hline No & 1.23 & $1.10,1.39$ \\
\hline \multicolumn{3}{|c|}{ Number of individuals in the household } \\
\hline Up to 4 individuals & 1.00 & - \\
\hline From 5 to 7 individuals & 1.95 & $1 \cdot 77,2 \cdot 16$ \\
\hline More than 8 individuals & 3.52 & $2 \cdot 90,4 \cdot 26$ \\
\hline \multicolumn{3}{|l|}{$\begin{array}{l}\text { Provision of care by Programa Saúde } \\
\text { da Família }\end{array}$} \\
\hline Yes & 1.00 & - \\
\hline No & 1.40 & $1.25,1.58$ \\
\hline \multicolumn{3}{|l|}{$\begin{array}{l}\text { Employment status of the head of the } \\
\text { household }\end{array}$} \\
\hline Employed & 1.00 & - \\
\hline Unemployed & 1.11 & $0.98,1.26$ \\
\hline Retired & 1.09 & $0.92,1.30$ \\
\hline
\end{tabular}

*All analysed variables showed statistical significance in the bivariate analysis using the $x^{2}$ test and considering a significance level of $P<0.05$. Adjusted OR by monthly per capita household income, educational level of the head of the household, region, Programa Bolsa Familia, Programa Cisternas, Programa Garantia Safra, adequate water supply, adequate sanitation, number of individuals in the household, provision of care by Programa Saúde da Familia and employment status of the head of the household.

tOR considering food-secure and mildly food-insecure households as the reference category $v$. moderately and severely food-insecure households.

(Midwest Brazil) a prevalence of $74.2 \%$ of HFI, with $45.1 \%$ having mild HFI, $21.6 \%$ having moderate HFI and $8.5 \%$ severe FI. The risk factors identified for HFI in these two smaller studies are highly consistent with those found in the present census analysis of officially recognized Quilombolas territories ${ }^{(8,19)}$. The studies conducted in the North and Midwest used the old EBIA version with fifteen items $v$. the fourteen-item EBIA, that excluded the weight loss item, used in our study. However, this difference in metric used does not explain the differences in HFI 
prevalence across studies as the HFI categories' classification is comparable between the fourteen-item and the fifteenitem scale ${ }^{(20)}$. The difference between these lower HFI estimates and ours is likely to be due to the differences in samples studied, namely a representative national sample $v$. a local sample, as well as sampling exclusion criteria. For example, the study in the Midwest enrolled only families with children attending public schools located near cities, and excluded remote communities which are the poorest ones and less likely to be able to benefit from public policies ${ }^{(19)}$.

There was a clear contrast between the North and Northeast regions and the remaining three Brazilian regions. These two regions have worse economic, social and health indicators compared with the others, including food shortages and food deprivation as documented in prior studies ${ }^{(3,21)}$. These findings confirm the persistence of geographical inequalities in the social determinants of health across regions in Brazil. Bezerra et al. ${ }^{(22)}$ found a high prevalence of hypertension associated with socioeconomic and demographic factors such as economic class and education among Quilombolas in a Northeast Brazilian municipality (Vitoria da Conquista). Kochergin et $a l .^{(23)}$ found in the same community that self-rated health was associated with socio-economic and demographic indicators, lifestyle, social support and health status. Gomes et al. ${ }^{(24)}$ documented an underutilization of health services by members of this same community.

Socio-economic and demographic determinants of poverty strongly influence ethnic/racial differentials in health and well-being in Brazil. In addition to the Quilombolas, the entire black and brown population experiences more socio-economic deprivation compared with its white counterpart ${ }^{(3)}$. Even though people of colour represent more than $50 \%$ of the Brazilian population $^{(25)}$, in 2009 blacks accounted for only $24 \%$ of those in the richest income decile ${ }^{(26)}$. Homicide victims in Brazil are most likely to be young, male, black and with few years of education, showing the marginalization of people of colour within Brazilian society ${ }^{(27)}$. Black men had an average of 6.7 years of studying, compared with 8.4 years for white men ${ }^{(26)}$. Thus the ethnic/racial inequities in Brazil go beyond the Quilombolas land borders.

Regarding educational level, our results are similar to those of a previous study showing that the majority of Quilombolas had low levels of literacy or had just a few years of education ${ }^{(9)}$. Our findings revealed that low educational level and poverty are risk factors for HFI among Quilombolas and this is supported by the fact that educational level is a major social determinant of health and well-being; indeed, it is the main determining factor of personal income in Brazil ${ }^{(3)}$.

Consistent with our results, a previous study documented that low income and extreme poverty were frequent among Quilombolas. Oliveira e Silva et al. ${ }^{(9)}$ observed that $29.7 \%$ of Quilombolas families living in a state localized in North Brazil did not generate any income. Our results about unemployment are consistent with those reported in the Quilombolas Nutritional Survey in $2006^{(7)}$ and in Oliveira e Silva et al.'s study ${ }^{(9)}$. In those two studies low income was explained at least in part by the high levels of unemployment in Quilombolas families.

Consistent with previous studies, our findings strongly support the conclusion that HFI is the result of income inequities and the social exclusion resulting from it. Low income is an important risk factor for HFI in Quilombolas because it is associated with less access to food ${ }^{(28)}$. Low income can be the result of a lack of access to agriculture as a source of income, the legal problems with land ownership that this population experiences, and the illiteracy prevalence that reduces the employment and better income opportunities $^{(2,7,9)}$. The lack of land ownership is an important challenge because of its major economic and social repercussions. Even if Quilombolas communities legally own their land, they often suffer expropriation by ranchers and land grabbers. These territorial issues make them revive the struggle for land and social injustices experienced by their ancestors with implications for income generation ${ }^{(29)}$.

In the past, Quilombolas had a traditional relationship with the land providing food and with subsistence agriculture being very important for their food security ${ }^{(29)}$. Nowadays, however, this has changed as the agricultural activities in Quilombolas communities have become increasingly difficult to maintain due to lack of credit, lack of tools, high production costs and low selling prices of crops. Furthermore, ecosystem degradation and climate change have diminished the availability of foods from fishing and hunting and have hindered the fertility of the soil $^{(9,10)}$. These major agriculture-related shifts have been accompanied by increased proximity to roads leading to urban areas and structural economic changes, including access to social programmes and wage labour, both of which have been associated with increased consumption of processed foods ${ }^{(19)}$. As a result, younger generations have lost their connection to the land and agriculture and their access to food has been monetized.

Widespread poverty has been associated with HFI among Quilombolas and the Brazilian population in general $^{(3)}$. On one hand, our study showed that families that did not receive benefits from Progama Bolsa Família were less likely to experience moderate and severe food insecurity, and the result remained statistically significant after adjusting for socio-economic and demographic confounders. This can be explained by the programme's focus, showing that it is well targeted ${ }^{(30)}$. People enrolled in this programme are in extreme poverty and experience worse conditions of HFI than those not enrolled; thus this cross-sectional finding is simply likely to be explained by reverse causality. On the other hand, families not participating in Programa Cisternas and Programa Garantia Safra had a higher chance of living in moderately or severely food-insecure households. This important finding shows the importance of these very specific programmes 
assisting vulnerable populations living in regions where weather conditions may generate water scarcity for consumption and for food production (Brazilian semi-arid region $)^{(15,16)}$. The Cisternas programme is responsible for maintaining water accessibility during dry seasons, for individual consumption or agricultural use ${ }^{(15)}$. The food security concept includes access to clean water ${ }^{(1)}$. Quilombolas communities' access to safe drinking-water and sewage systems is indeed limited, as shown before in previous studies ${ }^{(8,9)}$. This situation is closely related to a high prevalence of parasite infections and diarrhoeal diseases in the Quilombolas population ${ }^{(31)}$. The Programa Garantia Safra ensures that Quilombolas will be paid fairly for the food they are producing, guaranteeing minimum earnings to small family farms susceptible to crop losses due to drought or flood ${ }^{(16)}$.

Access to the Programa Saúde da Familia and to community health worker visits was mostly limited within households experiencing food insecurity, especially in those with the most severe forms of food insecurity. These findings corroborate those of other studies showing that Quilombolas have limited access to health-care services due to income-related factors and their geographical isolation, thus reinforcing social vulnerability ${ }^{(24,32-34)}$. A new programme named Mais Medicos was launched in 2013 in Brazil and initial analyses showed that the programme was providing access to doctors in primary health-care teams in remote rural municipalities with presence of Quilombolas communities ${ }^{(35)}$. It remains to be seen if the improvement of Quilombolas health care will also have impact on their household food security status.

The current study has some limitations. Although HFI was measured directly by EBIA, food consumption data were not available. Food consumption data may have helped characterize dietary quality at the household and intrahousehold levels. The high prevalence of HFI and the homogeneity of living conditions experienced by Quilombolas also may have made it more difficult to uncover more associations between socio-economic variables and HFI. Moreover, the present data were collected in communities officially recognized as Quilombolas, leaving out those families without land titles who may have had worst HFI status. Another limitation is the small number of previous studies investigating Quilombolas in Brazil, limiting us to compare our findings with only a handful of previous studies conducted in small samples or single communities $^{(8,9,19)}$. In spite of these limitations, our study is innovative because is based on a Census survey providing the most comprehensive analysis of HFI among Quilombolas to date. It is our hope that our findings will bring to the attention of the international community the prevalent social exclusion condition and food security needs of black-slave descendant communities in Brazil. In addition to the international perspective, the scientific evidence certainly supports revision of Brazilian public policies aimed to eliminate inequities experienced by Quilombolas ${ }^{(36)}$.

\section{Conclusion}

Food insecurity was highly prevalent in Quilombolas households and, as expected, was directly associated with socio-economic factors. There were clear HFI inequities across different Brazilian regions. Quilombolas in Brazil experience high levels of HFI, but also poor quality of life, poor health, poor diet and non-dignified living conditions. Thus, the historical legacy of social exclusion and social vulnerability continues to be strongly present among those of black slave descent.

Through this innovative census application of EBIA in a highly vulnerable context, the findings can help Brazil improve food security governance among Quilombolas communities $^{(36)}$. Although there are several public policies, social programmes and benefits currently established in Brazil, there still is a low coverage in Quilombolas communities. In order to improve living conditions and, consequently, the food and nutrition security status in Quilombolas communities, the Government should take into account the needs and wants of this population regarding access to basic rights as well as the governmental social programmes. These programmes should include actions that promote credit and access to tools for family agriculture, respect culturally accepted dietary practices, foster food and nutrition education activities that promote healthy diets, and improve sanitation conditions and hygiene practices that increase the biological utilization of foods, thereby ensuring food security in all its dimensions.

\section{Acknowledgements}

Financial support: This research was funded by the Ministry of Social Development and Fight Against Hunger (Ministério de Desenvolvimento Social e Combate à Fome, MDS) and the National Council for Scientific and Technological Development (Conselbo Nacional de Desenvolvimento Científico e Tecnológico, CNPq) (grant numbers 456699/2013-9 and 232569/2014-2). MDS and CNPq had no role in the design, analysis or writing of this article. Conflicts of interest: None. Authorship: M.B.G. designed the proposed study analysis; A.M.S., J.P., S.E.A. C.C. and A.M.S.-C. performed statistical analyses; A.M.S., J.P. and S.E.A.C.C. wrote the first version of the manuscript; A.M.S.-C. helped in resolving methodological issues; M.B.G., R.P.-E. and A.M.S.-C. made substantial contributions to the interpretation of results and writing of the manuscript. All authors approved the final version of the manuscript. Ethics of buman subject participation: Ethics approval was not required for this paper. The data are secondary and came from a national census including all Quilombolas households made by the Brazilian Government. We used de-identified data available in the public domain. This study was exempt from approval by a research ethics committee. 


\section{References}

1. Presidência da República, Casa Civil, Subchefia para Assuntos Jurídicos, Brasil (2006) Lei no 11.346, de 15 de setembro de 2006. Cria o Sistema Nacional de Segurança Alimentar e Nutricional com vistas em assegurar o direito humano à alimentação adequada e dá outras providências. Diário Oficial da União, 18 setembro.

2. Ministério do Desenvolvimento Social e Combate à Fome \& Secretaria de Avaliação e Gestão da Informação (2014) Quilombos do Brasil: Segurança Alimentar em Territórios Titulados. Cadernos de Estudos - Desenvolvimento Social em Debate número 20. Brasília, DF: MDS.

3. Instituto Brasileiro de Geografia e Estatísticas (2014) Pesquisa Nacional por Amostra de Domicílios (PNAD). Segurança Alimentar: 2013. Rio de Janeiro, RJ: IBGE.

4. Instituto Brasileiro de Geografia e Estatísticas (2010) Pesquisa Nacional por Amostra de Domicílios (PNAD). Segurança Alimentar 2004/2009. Rio de Janeiro, RJ: IBGE.

5. Instituto Brasileiro de Geografia e Estatísticas (2013) Síntese de Indicadores Sociais - Uma Análise das Condições de Vida da População Brasileira: 2013. Estudos e Pesquisa Informação Demográfica e Socioeconômica número 32. Rio de Janeiro, RJ: IBGE.

6. Presidência da República, Casa Civil, Subchefia para Assuntos Jurídicos, Brasil (1988) Constituição da República Federativa do Brasil de 1988. Promulgada em 5 de outubro de 1988. http://www.planalto.gov.br/ccivil_03/Constituicao/ Constituicao.htm (accessed September 2016).

7. Ministério do Desenvolvimento Social e Combate à Fome \& Secretaria de Avaliação e Gestão da Informação (2007) Chamada Nutricional Quilombola 2006: Sumário Executivo. Brasília, DF: MDS.

8. Monego ET, Peixoto MRG \& Cordeiro MM (2010) Food insecurity of Tocantins's quilombolas communities. Seg Aliment Nutr Campinas 17, 37-47.

9. Oliveira e Silva D, Guerrero AFH, Guerrero CH et al. (2008) The causality of nutrition and food insecurity of quilombola communities with the construction of the BR-163 highway, Pará, Brazil. Rev Nutr 21, 83-97.

10. Carvalho AS \& Oliveira e Silva D (2014) Prospects of food and nutritional security in the Tijuaçu Quilombo, Brazil: family agricultural production for school meals. Interface (Botucatu) 18, issue 50, doi: 10.1590/1807-57622013.0804.

11. Presidência da República, Secretaria de Políticas de Promoção da Igualdade Racial \& Secretaria de Políticas para Comunidades Tradicionais (2013) Guia de Políticas Públicas para Comunidades Quilombolas. Programa Brasil Quilombola. http://www.seppir.gov.br/portal-antigo/arqui vos-pdf/guia-pbq (accessed September 2016).

12. Bickel G, Nord M, Price C et al. (2000) Guide to Measuring Household Food Security (Revised 2000). Alexandria, VA: US Department of Agriculture, Food and Nutrition Service.

13. Segall-Corrêa AM, Pérez-Escamilla R, Marin-León LL et al. (2009) Evaluation of Household Food Insecurity in Brazil: Validity Assessment in Diverse Sociocultural Settings. Santiago: Oficina Regional FAO Chile; available at http://www.bvsde. paho.org/texcom/nutricion/memredsan_3.pdf

14. Ministério do Desenvolvimento Social e Combate à Fome \& Secretaria de Avaliação e Gestão da Informação (2014) Questões Metodológicas Acerca do Dimensionamento da Extrema Pobreza no Brasil nos Anos 2000. Estudo Técnico número 08/2014. Brasília, DF: MDS.

15. Ministério do Desenvolvimento Social e Combate à Fome (2016) Programa Cisternas - Água para Beber e para Agricultura. http://mdspravoce.mds.gov.br/seguranca-alimentare-nutricional/programa-cisternas-agua-para-beber-e-paraagricultura/ (accessed April 2016).
16. Ministério do Desenvolvimento Agrário (2016) Garantia-Safra. http://www.mda.gov.br/sitemda/secretaria/saf-garantia/sobreo-programa (accessed April 2016).

17. Cabral CS, Lopes AG, Lopes JM et al. (2014) Food security, income, and the Bolsa Família program: a cohort study of municipalities in Paraíba State, Brazil, 2005-2011. Cad Saude Publica 30, 393-402.

18. Ferreira HS, Souza MECA, Moura FA et al. (2014) Prevalence and factors associated with food and nutrition insecurity in families in municipalities of the north of the State of Alagoas, Brazil, 2010. Cienc Saude Colet 19, 1533-1542.

19. Cordeiro MM, Monego ET \& Martins KA (2014) Overweight in Goiás' quilombola students and food insecurity in their families. Rev Nutr 27, 405-412.

20. Segall-Corrêa AM, Marin-León L, Melgar-Quiñones H et al. (2014) Refinement of the Brazilian Household Food Insecurity Measurement Scale: recommendation for a 14-item EBIA. Rev Nutr 27, 241-251.

21. Gubert MB, Benício MHD \& Santos LMP (2010) Estimates of severe food insecurity in Brazilian municipalities. Cad Saude Publica 26, 1595-1606.

22. Bezerra VM, Andrade ACS, César CC et al. (2013) Quilombo communities in Vitória da Conquista, Bahia State, Brazil: hypertension and associated factors. Cad Saude Publica 29, 1889-1902.

23. Koshergin CN, Proietti FA \& César CC (2014) Slavedescendent communities in Vitória da Conquista, Bahia State, Brazil: self-rated health and associated factors. Cad Saude Publica 30, 1487-1501.

24. Gomes KO, Reis EA, Guimarães MDC et al. (2013) Use of health services by quilombo communities in southwest Bahia State, Brazil. Cad Saude Publica 29, 1829-1842.

25. Instituto Brasileiro de Geografia e Estatística (2011) Censo Demográfico de 2010. Brasília, DF: IBGE.

26. Instituto de Pesquisa Econômica e Aplicada (2011) Retrato das Desigualdades de Gênero e Raça, $4^{\mathrm{a}}$ ed. Brasília, DF: IPEA.

27. Murray J, Cerqueira DRC \& Khan T (2013) Crime and violence in Brazil: systematic review of time trends, prevalence rates and risk factors. Aggress Violent Behav 18, 471-483.

28. Anschau FR, Matsuo T \& Segall-Corrêa AM (2012) Food insecurity among recipients of government assistance. Rev Nutr 25, 177-189.

29. Furtado MB, Pedroza RL \& Alves CB (2014) Quilombola culture, identity and subjectivity: a cultural psychology perspective. Psicol Soc 26, 106-115.

30. Segall-Corrêa AM, Marin-León L, Pérez-Escamilla R et al. (2008) Cash transference and food insecurity in Brazil: analysis of national data. Rev Nutr PUCCAMP 21, Suppl. $39-51$.

31. Andrade EC, Leite ICG, Vieira MT et al. (2011) Prevalence of parasitic intestinal diseases in a quilombola community, in the Municipality of Bias Fortes, State of Minas Gerais, Brazil, 2008. Epidemiol Serv Saude 20, 337-344.

32. Guerrero AFH, Oliveira e Silva D, Toledo LM et al. (2007) Infant mortality rates in quilombo areas of the Municipality of Santarém - Pará, Brazil. Saude Soc 16, 103-110.

33. Silva JAN (2007) Sanitary and health conditions at Caiana dos Crioulos, a quilombo community in the State of Paraiba. Saude Soc 16, 111-124.

34. Volochko A (2009) Health in quilombos. In Saúde nos Quilombos, pp. 147-168 [A Volochko and E Batista E, editors]. São Paulo, SP: Instituto de Saúde.

35. Pereira LL, Santos LMP, Santos W et al. (2016) Mais Médicos program: provision of medical doctors in rural, remote and socially vulnerable areas of Brazil, 2013-2014. Rural Remote Health 16, 3616.

36. Pérez-Escamilla R (2012) Can experience-based household food security scales help improve food security governance? Glob Food Sec 1, 120-125. 